\title{
Sinergitas Pembangunan Tata Ruang Pertahanan Daerah dalam Menghadapi Ancaman Non-Militer di Indonesia
}

\author{
Alfajri, Azhari Setiawan, Herry Wahyudi \\ Universitas Abdurrab, Riau
}

\begin{abstract}
ABSTRAK
Artikel ini bertujuan untukmemahami dan menjelaskan konteks lokal daripertahanan negara terhadap ancaman non-militer di Indonesia. Seiring dengan perkembangan perluasan dan pendalaman makna keamanan, agenda keamanan non-tradisional membutuhkan sinergi multi-level dan multi-sektor terutama di pemerintahan daerah karena perkembangan ancaman non-militer di Indonesia cukup banyak berkembang di daerah. Pertama, penulis mengulas sejumlah literatur tentang keamanan non-tradisional, ancaman non-militer, dan teori sekuritisasi. Kedua, artikel ini mengelaborasi lingkungan strategis-global, regional, dan nasional-serta persepsi ancaman dari perspektif postur pertahanan Indonesia. Setelah itu, artikel ini menjelaskan aspek sekuritisasi dari sinergitas multi-level dan multi-sektor dalam menghadapi ancaman non-militer di tingkat daerah. Penulis kemudian berargumen bahwa sinergi pembangunan nasional, pembangunan daerah dan pembangunan pertahanan negara perlu dilakukan dengan didukung regulasi yang jelas, juga dengan memperhitungkan sumber daya yang tersedia guna tercapainya kesejahteraan masyarakat yang nyata, baik dalam aspek pendapatan, kesempatan kerja, lapangan usaha, akses terhadap pengambilan kebijakan, berdaya saing, maupun peningkatan indeks pembangunan manusia. Sinergitas antar pemangku kepentingan dalam sinergitas pembangunan pertahanan negara merupakan hal yang pokok untuk mencapai pertahanan yang tangguh. Sosialisasi kebijakan antar Instansi Vertikal Kementerian/Lembaga dan Pemerintah Daerah perlu dioptimalkan dan diintensifkan sehingga akan tercapai suatu persamaan persepsi dalam pengelolaan dan penyelenggaraan pembangunan pertahanan negara.
\end{abstract}

Kata Kunci: Ancaman non-militer, keamanan non-tradisional, Indonesia, sinergitas multilevel dan multi sektor.

This article aims to understand and explain the local context of state's defense toward non-military threats in Indonesia. As the broading and deepening development of security significance, non-traditional security agenda urges multi-levels and multi-sectors synergy especially in the local government because the nature of non-military threats in Indonesia developed at the local level. First, authors review numbers of literatures about non-traditional security, non-military threats and the securitization theory. Second, the article elaborates the strategic environment-global, regional, and national-and threats perception from the perspective of Indonesia's defense posture. After that, the article explains securitization aspects of multi-level and multi-sectors synergy on facing the non-military threats at the local level. The result of this research is the synergy of national development, regional development and national defense development needs to be synchronized with the support of clear regulations, considering the available resources to achieve real community welfare, both in terms of income, employment opportunities, business opportunities, access to policy making, competitiveness, and an increase in the human development index. The strategic relations between stakeholders in the synergy of national defense development is essential to achieve formidable defense. Policy socialization between vertical agencies of ministries/ institutions and regional governments needs to be optimized and intensified so that there will be a common perception in the management and implementation of national defense development on dealing with non-military threats.

Keywords: Non-military threats, non-traditional security, Indonesia, multi-level and multisector synergy 
Studi dan praktik pertahanan dan keamanan saat ini tengah mengalami dua fenomena yang saling berkaitan. Fenomena pertama disebut sebagai perluasan makna keamanan. Perluasan makna keamanan berarti bahwa pertahanan saat ini tidak lagi hanya berbicara tentang permasalahan-permasalahan militer saja, namun meluas ke sektorsektor lain seperti sektor sosial, ekonomi, budaya, dan lingkungan. Lalu, fenomena yang kedua disebut sebagai pendalaman makna keamanan. Artinya, pertahanan dan keamanan tidak lagi menempatkan pemerintah atau negara sebagai aktor utama. Aktor keamanan baik itu subjek maupun objek keamanan menjadi semakin membumi mengikutsertakan individu dan kelompok individu sebagai aktor. Hal inilah yang melatarbelakangi munculnya aliran-aliran pemikiran baru seperti Keamanan Manusia, Keamanan Kritis, Madzhab Copenhagen (Sekuritisasi), dan studi mengenai ancaman nonmiliter dan keamanan nontradisional.

Permasalahan-permasalahan keamanan saat ini menjadi begitu kompleks dan rumit. Aspek ancaman lebih kompleks dengan dinamika kerawanan yang wujudnya lebih sulit untuk diprediksi. Permasalahan yang berkaitan dengan ancaman nonmiliter justru lebih efektif menjadi tanggung jawab utama pihak daerah karena pada dasarnya isu-isu nonmiliter yang sangat menitikberatkan pada aspek-aspek individu ini hadir di tengah-tengah masyarakat. Oleh karena itu perlu adanya sebuah sinergitas antara pemerintah pusat sebagai aktor yang melakukan sekuritisasi dan juga pihak yang mengeluarkan tindak tutur terkait ancaman nonmiliter dan keamanan nontradisional dengan pemerintah daerah yang secara langsung berada di garis depan pertahanan negara dalam menghadapi ancaman nonmiliter tersebut.

Kebijakan penyelenggaraan pertahanan negara merupakan pedoman dalam mempersiapkan pertahanan negara untuk menjaga kedaulatan negara, keutuhan wilayah, dan melindungi segenap bangsa, sekaligus untuk memberikan rasa aman kepada seluruh warga negara. Hal ini perlu dilakukan berdasarkan identifikasi kepentingan nasional dalam memperkuat jati diri bangsa sebagai negara kepulauan dan negara maritim dengan menempatkan Indonesia sebagai poros maritim dunia.

Untuk dapat mewujudkan arah dan sasaran kebijakan pertahanan negara tersebut, maka perlu dibuat sebuah agenda untuk membangun dan meningkatkan sinergitas antara pemerintah pusat dan pemerintah daerah dalam menciptakan tata ruang daerah dan tata ruang pertahanan daerah yang tangguh dan dapat menciptakan rasa aman bagi masyarakat, serta membangun stabilitas pertahanan dan keamanan negara.

Indonesia adalah negara kepulauan. Letaknya yang sangat strategis di antara dua benua dan dua samudera, telah menjadikan Indonesia sebagai salah satu jalur utama lalu lintas internasional. Posisi strategis tersebut berpotensi besar terhadap perkembangan lingkungan strategis dan dinamika konstelasi antar bangsa dengan kepentingan nasionalnya masing-masing. Hal ini menuntut Indonesia untuk membangun tata ruang pertahanan dan arsitektur keamanan yang mampu menghadapi ancaman, tantangan, hambatan, serta gangguan yang muncul dari dinamika konstelasi politikkeamanan di kawasan.

Tuntutan ini sejalan dengan posisi sentral negara sebagai penyedia keamanan. Negara dalam pandangan Thomas Hobbes berperan dalam mempertahankan dan melindungi masyarakat dari invasi asing serta kerusakan dan konflik antar sesama (Buzan, 1983). Pandangan ini memiliki dua dimensi yaitu: 1) dimensi eksternal bahwa negara wajib siaga menghadapi ancaman dari luar dan 2) dimensi internal ketika negara wajib 
siaga mengatasi kerawanan dari dalam yang muncul karena potensi-potensi konflik tertentu.

Aspek kerawanan dari dalam ini kemudian menjadi salah satu perbincangan inti baik dari segi akademik, maupun fenomena di lapangan, bahwa makna keamanan tidak lagi hanya berkutat pada ancaman militer saja, namun juga sudah mengarah pada ancaman dan kerawanan nonmiliter/nirmiliter. Salah satu aliran pemikiran keamanan baru, Mazhab Copenhagen, yang dibangun oleh Barry Buzan dan Ole Weaver mengkaji sebuah fenomena baru yang dikenal dengan "Perluasan dan Pendalaman Makna Keamanan”. Seiring dengan perkembangannya, keamanan mengalami perluasan dan pendalaman makna. Perluasan berarti bahwa keamanan tidak lagi berbicara soal militer saja, sedangkan pendalaman berarti bahwa keamanan tidak lagi menempatkan negara sebagai aktor utama, keamanan juga melibatkan aktor lain selain negara seperti individu dan kelompok masyarakat. Berdasarkan pada dua tren perkembangan studi keamanan tersebut, Barry Buzan dan Ole Weaver dalam 'Security: A New Framework for Analysis' berbicara mengenai tiga hal yang dianggap esensial bagi studi keamanan versi Mazhab Copenhagen. Pertama, Buzan dkk memperkenalkan teori sekuritisasi sebagai kerangka baru dalam menganalisis isu-isu keamanan baru (non-militer). Kedua, Buzan dkk mengkritik paradigma keamanan tradisional yang terlalu statecentric dan military-centric dengan mengemukakan empat sektor dalam teori sekuritisasi terdiri dari: 1) militer, 2) lingkungan, 3) ekonomi, 4) sosial dan 5) politik.

Perhatian pada ancaman dan kerawanan nonmiliter ini juga menjadi perhatian khusus di Indonesia. Menteri Pertahanan Indonesia, Ryamizard Ryacudu, menyatakan ada delapan manifestasi ancaman nonmiliter (asimetrik) dalam konteks bela negara antara lain: 1) Terorisme; 2) Bencana Alam; 3) Pelanggaran Perbatasan; 4) Separatisme; 5) Penyakit Menular; 6) Serangan Siber; 7) Narkoba; dan 8) Infiltrasi Budaya (Kompas 2016; Antara News 2016). Selain itu juga Kementerian Pertahanan Republik Indonesia lewat Buku Putih Pertahanan Indonesia 2015 juga telah mengemukakan pembagian ancaman saat ini terbagi tiga antara lain: ancaman militer, non militer, dan hibrida. Sumber ancaman dapat berasal dari dalam maupun luar negeri, serta dilakukan oleh actor negara maupun non negara, yang bersifat nasional, regional, dan internasional. Dampak yang ditimbulkan meliputi segala aspek kondisi sosial seperti ideologi, politik, ekonomi, sosial-budaya, pertahanan, dan keamanan. Pandangan pertahanan dan keamanan Indonesia yang termaktub dalam Buku Putih Pertahanan dinilai cukup baik dalam mengadopsi dan menerjemahkan dinamika keamanan di tingkat internasional dan regional, ke tingkat nasional. 
Gambar 1.

Tipologi Ancaman Berdasarkan Buku Putih Pertahanan Indonesia 2015

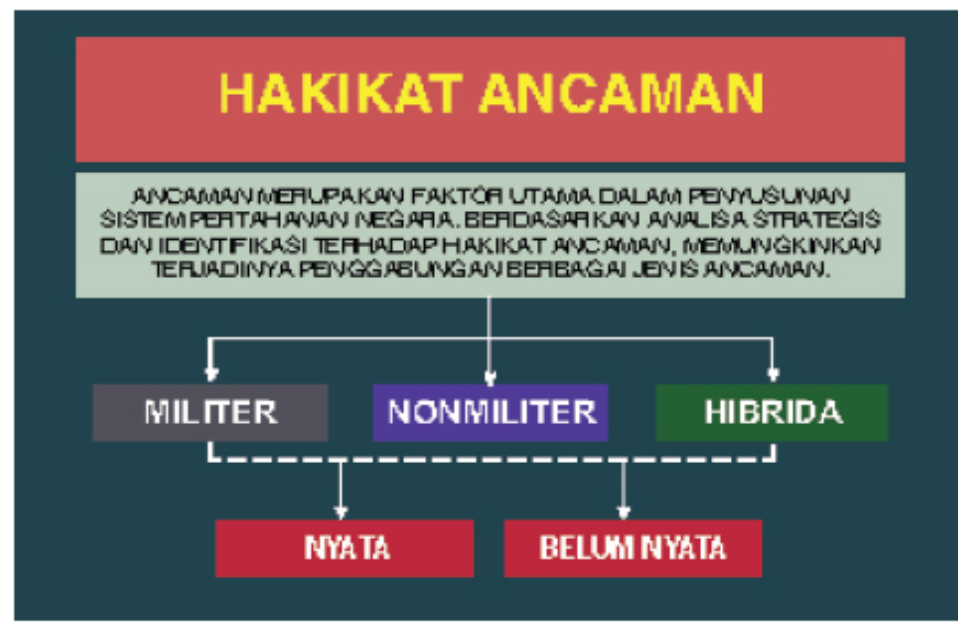

Sumber: Buku Putih Pertahanan Indonesia, 2015

Asimetrisme yang melahirkan ancaman nonmiliter mengacu pada karakter konflik negara dan musuhnya yang memiliki perbedaan-perbedaan yang signifikan, baik berupa aktor negara, non-negara maupun maupun hibrida. Asimetrisme secara konsep memiliki tiga aspek yaitu: 1) Asimetri Kepentingan; 2) Asimetri Ideologi; dan 3) Asimetri Kapabilitas. Artinya, perang asimetris berbicara tentang perang antar aktor yang memiliki kepentingan, ideologi, dan kapabilitas yang asimetris (secara signifikan bereda)(Thornton 2007).

Berdasarkan pada kondisi tersebut, visi pertahanan Indonesia mengarah pada doktrin pertahanan teritorial sebagai perhatian utama. Di awal tahun 1958, para pemikir pertahanan Indonesia merumuskan konsep pertahanan teritorial yang tidak hanya berbasis pada retaliasi terhadap negara luar, namun lebih berfokus untuk membangun teritorial Indonesia yang sulit untuk ditaklukkan baik dari luar (eksternal) dan juga dari dalam (internal). Setelah tahun 1980an pada masa kepemimpinan Jenderal Murdani, pasca perkembangan ekonomi Indonesia, pemerintah kemudian memformulasikan perluasan makna keamanan untuk mewujudkan dimensi keamanan yang lain sebagai sebuah pertahanan geostrategik yang mumpuni.

Pendekatan pertahanan dan keamanan pemerintah Indonesia dikenal dengan "Sishankamrata", Sistem Pertahanan dan Keamanan Rakyat Semesta atau disebut juga sebagai “Total Defence Sistem”. Leonard Sebastian menjelaskan Sishankamrata pada awalnya merupakan strategi pertahanan melawan invasi eksternal yang didasarkan pada kerjasama antara pasukan/kekuatan bersenjata dan populasi dalam melancarkan perang lewat aksi gerilya ketika berkonfrontasi dengan kekuatan superior yang konvensional(Sebastian, 2006). Perkembangan kemudian memperluas dan memperdalam makna rakyat semesta menjadi lebih professional-based dan perkembangan studi keamanan yang juga dibarengi dengan agenda reformasi sektor pertahanan Indonesia ikut memperluas dan memperdalam makna keamanan Indonesia sehingga visi keamanan tersebut juga melingkupi aspek-aspek vital di social-kemasyarakatan, tidak hanya aspek kemiliteran dan ancaman invasi dari luar.

Karakteristik dari Sishankamrata tersebut antara lain: 1) resistensi tanpa gangguan; 2) 
dijalankan oleh unit besar dan kecil secara terpisah dengan fleksibilitas; 3) di bawah kepemimpinan yang konstan; 4) sentralisasi strategi dan desentralisasi implementasi; 5) fleksibilitas waktu dan ruang; 6) pantang menyerah (no surrender); 7) dijalankan dengan tiga fase frontal, konsolidasi-tantangan-penahanan, dan konter-ofensif; 8) keselarasan kepemimpinan nasional dan identitas nasional. Kesuksesan strategi perang teritorial dapat dilihat melalui: 1) stabilisasi medan politik; 2) asas tunggal Pancasila; 3) otoriras kepemimpinan yang tunggal; 4) integrasi menyeluruh antar divisi pertahanan; 5) perencanaan yang maksimal; dan 6) manajemen Teritorial (Sebastian, 2006). Karakteristik ini diharapkan dapat dimaksimalkan bagi negara dalam mengatasi kerawanan dan ancaman, terutama ancaman nonmiliter.

Konsepsi tersebut didasari oleh sebuah Grand Strategy, dengan tiga situasi yang direncanakan: 1) Sebelum perang: penguatan dan persiapan akan adanya ancaman; 2) Masa perang: penggunaan seluruh potensi negara untuk menunjang pertahanan dan keamanan; 3) Pasca perang: mengatasi hasil dari perang baik secara material dan spiritual. Indonesia juga melakukan Operasi Bersama dengan negara-negara lain untuk menjaga pertahanan dan keamanan bersama. Secara geografis Indonesia memaknai bahwa ancaman yang datang ke Indonesia berpotensi tinggi masuk lewat jalur Barat dan Timur dan hampir dari keseluruhan target ini lewat jalur laut.

Meskipun berdasarkan analisis perkembangan lingkungan strategis, ancaman yang datang dari luar negeri dalam bentuk invasi dinilai sangat kecil kemungkinannya, adanya beberapa kerawanan dan peluang terhadap timbulnya konflik, merupakan suatu isyarat untuk tetap meningkatkan kewaspadaan dan kepekaan agar dapat segera dilakukan antisipasi sebelum berkembang secara nyata menjadi suatu gejolak yang dapat mengganggu stabilitas keamanan nasional.

Pada tataran ini, posisi Pemerintah Daerah menjadi begitu penting, sesuai dengan yang tertera pada Buku Putih Pertahanan Indonesia 2015 bahwa dalam skema sistem pertahanan negara, pertahanan nirmiliter menempatkan Kementerian/Lembaga lain dan Pemerintah Daerah sebagai unsur utama yang harus berperan dalam mengantisipasi dan mencegah terjadinya ancaman nonmiliter melalui penataan ruang wilayah nasional dan terutama daerah dengan tata ruang wilayah pertahanan untuk mewujudkan ruang pertahanan yang tangguh (Kementerian Pertahanan, 2015). Pembangunan wilayah pertahanan negara harus diselenggarakan secara terintegrasi antara unsur Pemerintah dan Pemerintah Daerah agar dapat secara maksimal menghadapi ancaman nonmiliter baik ancaman nyata maupun ancaman belum nyata (potensial).

\section{Tinjauan Pustaka}

Kajian mengenai Ancaman Nonmiliter dalam Studi Keamanan banyak dibahas dalam tema-tema tentang Keamanan Non-Tradisional. Berdasarkan perkembangan studi keamanan yang telah berjalan beberapa dekade ini, makna keamanan telah mengalami perluasan dan pendalaman seperti yang penulis telah sampaikan sebelumnya pada Bab Pendahuluan, dimana perluasan dan pendalaman makna keamanan ini turut berkontribusi dalam mengembangkan preposisi baru yaitu ancaman tidak lagi bersifat militer saja namun juga bersifat nonmiliter.

Barry Buzan dalam "People, State, and Fear" menempatkan negara sebagai institusi 
sah penyedia keamanan yang memiliki posisi sentral dalam mengatasi segala bentuk ancaman. Mengenai ancaman, Barry Buzan menyatakan bahwa ancaman keamanan sebuah negara tidak hanya bersifat militer saja, namun juga nonmiliter. Buzan juga menjelaskan bahwa referent object tidak hanya stabilitas keamanan negara, namun juga individu dan sistem. Barry Buzan juga mengenalkan aspek-aspek ancaman nonmiliter berupa: 1) ancaman fisik, 2) ancaman social, 3) ancaman terhadap HAM, dan 4) ancaman terhadap posisi dan status (sosial)(Buzan, 1983).

Negara, menurut Barry Buzan , sangat sentral dalam menangani masalah keamanan karena empat aspek yang dimilikinya dan tidak dimiliki oleh aktor yang lain antara lain: 1) otoritas publik, 2) legitimasi, 3) kekuatan koersif, dan 4) pengaruh untuk mengelola kepatuhan. Empat aspek inilah yang membuat negara mampu menangani permasalahan-permasalahan keamanan baru yang sifatnnya nonmiliter namun memiliki potensi yang besar untuk mengganggu stabilitas keamanan negara dan keamanan masyarakat(Buzan, 1983).

Literatur selanjutnya adalah Mely Caballero-Anthony dan Alistair D.B. Cook dalam "Non-Traditional Security in Asia: Issues, Challenges, and Framework for Action". Mely dan Cook mencoba mengelaborasi keamanan nontradisional dari berbagi sisi. Mereka menyetujui bahwa dalam dinamika keamanan insani, ancaman dapat dikategorikan menjadi dua: state-sponsored military dan non-military. Segala hal yang secara teknis bersifat nonmliter, berada di ranah Keamanan Non-Tradisional, baik di level lokal, nasional, regional, dan internasional atau global (Mely \& Cook 2013). Literatur ini menjabarkan bahwa ancaman nonmiliter bersumber dari beberapa isu seperti kesehatan, pangan, air, bencana alam, konflik internal, migrasi, energi, kejahatan transnasional, dan keamanan siber. Penekanan pada literature ini adalah "non-military threats to the safety of societies, groups, and individuals (ancaman nonmiliter terhadap keselamatan dan keamanan masyarakat, kelompok, dan individu)". Tata Kelola (governance) adalah solusi yang dikemukakan oleh Mely dan Cook dalam menangani permasalahan keamanan nontradisional. Literatur ini menyediakan delapan indikator sebagai bahan assessment dan juga acuan atau kerangka kebijakan strategis antara lain: 1) partisipasi, 2) rule of law, 3) transparansi, 4) keresponsifan, 5) kebijakan yang berorientasi pada consensus, 6) kesetaraan dan keinklusifan, 7) efektifitas dan efisiensi, dan 8) akuntabilitas (Mely \& Cook 2013).

Selanjutnya, Mely Caballero-Anthony mengangkat tema ini dalam Working Paper yang diterbitkan oleh Centre for Non-Traditional Security Studies S. Rajaratnam School of International Studies, Singapura dalam tajuk "Non-Traditional Security Challenges Regional Governance, and the ASEAN Political-Security Community". Dalam tulisan tersebut, Mely mengemukakan bahwa perlu adanya kerjasama antarlevel baik secara horizontal maupun vertikal dalam menghadapi ancaman-ancaman nonmiliter/ nontradisional. Agenda ini bergantung pada level mana ia berkembang dimulai dari level yang paling rendah di tingkat lokal, sampai pada level internasional atau global. Pendekatan "Keamanan Komprehensif" perlu didorong dan dimaksimalkan dalam pelaksanaan Komunitas Politik-Keamanan ASEAN jika ASEAN ingin menghadapi ancaman tersebut secara maksimal. Aspek multilateralisme yang dijadikan oleh Mely sebagai pendekatan dan ruang lingkup dapat diadopsi dan diadaptasikan dengan permasalahan keamanan nontradisional di tingkat lokal dengan aspek multilokalisme antar pemerintah daerah. Hal ini dinilai mampu meningkatkan sinergitas tidak hanya di dalam tubuh pemerintah daerah namun juga berpotensi untuk mendorong berkembangnya sinergitas antar pemerintah daerah yang secara wilayah beririsan 
dan memiliki keterhubungan untuk menyelesaiakan masalah yang sama (CaballeroAnthony 2010).

J. Peter Burgess dalam Non-Military Security Challenges menyatakan bahwa tantangan-tantangan yang ada di hadapan kita terkait dengan dinamika Ancaman Non militer antara lain: 1) ketidakmanan yang bersumber dari dinamika hubungan antar individu, 2) ketidakamanan sosietal, 3) arus perpindahan manusia atau migrasi, 4) perubahan iklim, 5) sumber daya alam dan air, 6) energi, 7) kejahatan transnasional, 8) perdagangan manusia, 9) perdagangan senjata, dan 10) kesehatan. Untuk menghadapi tantangan-tantangan ini, para akdemisi dan juga pemangku kebijakan dapat menjadikan 1) komersialisasi keamanan, 2) penyedia keamanan, 3) teknologisasi keamanan, 4) globalisasi keamanan, dan 5) intensitas berkembangnya "production of insecurity" sebagai center for gravity dalam melihat penyelesaian masalah-masalah yang diakibatkan oleh ancaman-ancaman nonmiliter (Burgess 2007).

Kemudian Hakan Wiberg dalam "Social and Cultural Origins of Violence: Non-Military Aspects of International Security" menjelaskan bahwa isu sentral dalam keamanan terbaru terletak pada bagaimana meminimalisir dan mengatasi kekerasan fisik dan non-fisik yang menyerang individu-individu sebagai salah satu entitas dalam sistem kemasyarakatan. Kekerasan terhadap individu yang tidak terselesaikan dengan baik akan berpotensi meningkat menjadi kekerasan kolektif. Hal inilah yang menyebabkan terjadinya kerusuhan besar-besaran dan bahkan perang sipil di taraf yang paling tinggi. Tulisan ini berusaha menjelaskan bahwa seluruh isu-isu nontradisional dan ancaman-ancaman nonmiliter yang ada bermuara pada satu masalah, yakni, kekerasan terhadap individu, kelompok, dan masyarakat yang mengakibatkan hilangnya otoritas hukum dan meningkatkan pelanggaran HAM. Tulisan ini mengangkat "Sosialisasi" sebagai langkah strategis dalam menangani ancaman-ancaman non militer. Agenda ini memfokuskan pada pendidikan dan media massa sebagai "Agen Sosialisasi" yang mampu meminimalisasi terjadinya kerusakan-kerusakan nontradisional atau nonmiliter. Penanganan secara stuktural dan kultural dinilai mampu menjadi langkah efektif dan efisien dalam menghadapi ancaman-ancaman non militer baik yang nyata maupun potensial (Wiberg 1995).

Roland Paris dalam "Human Security: Paradigm Shift or Hot Air" lebih memilih untuk menggunakan istilah "keamanan manusia" untuk merujuk pada masalah-masalah keamanan nontradisional yang bersumber dari ancaman-ancaman nonmiliter. Keamanan Insani (human security) adalah keamanan yang berorientasi pada manusia (human-oriented), tidak seperti kajian keamanan tradisional yang sifatnya "state-centric". Roland Paris menyatakan bahwa keamanan insani merepresentasikan sebuah paradigma baru bagi akademisi dan praktisi keamanan. Barry Buzan, Richard Wyn Jones, dll juga menyatakan hal yang serupa terkenal dengan istilah "pendalaman dan perluasan" konsep keamanan. Perluasan berarti bahwa keamanan tidak lagi berbicara soal militer saja, sedangkan pendalaman berarti bahwa keamanan tidak lagi menempatkan negara sebagai aktor utama, keamanan juga melibatkan aktor lain selain negara (Paris 2001).

Namun konsep keamanan insani masih memiliki sejumlah kritik. Roland Paris berpendapat ada dua kritik mengapa konsep keamanan insani sulit untuk digunakan sebagai panduan praktikal bagi riset akademik atau perumusan kebijakan yaitu: 1) definisi yang tidak terlalu seksama (precise); dan 2) ambiguitas tanggung jawab keamanan yang terlalu banyak aktornya. Konsep keamanan insani memang telah 
membuat banyak negara dan aktor lain berkoalisi membentuk wajah baru politik internasional sejak berakhirnya Perang Dingin, namun mengatakan Keamanan Insani memberikan fungsi-fungsi advokasi tentang keamanan itu berbeda dengan mengklaim bahwa konsep Keamanan Insani menawarkan kerangka analisis yang berguna dan mutakhir (Paris 2001).

Definisi baku tentang Keamanan Insani pertama kali muncul pada tahun 1994 dalam Human Development Report, sebuah dokumen tahunan dari UNDP. Keamanan Insani menurut UNDP memiliki dua aspek definisi yaitu: 1) keselamatan dari ancaman kronis seperti kelaparan, penyakit, dan represi; dan 2) proteksi dari gangguan yang sifatnya tiba-tiba dan dapat melukai saat melakukan aktivitas sehari-hari baik di rumah, perkejaan, komunitas, dll. Dua pengertian ini dalam kajian keamanan insani dikenal dengan pendekatan "Broad" dan "Narrow". Definisi ini sangat luas oleh karena itu disebutkan beberapa kategori yang termasuk dalam wilayah Keamanan Insani yaitu: 1) keamanan ekonomi; 2) keamanan pangan; 3) kesehatan; 4) keamanan lingkungan; 5) keamanan personal; 6) keamanan komunitas; dan 7) keamanan politik (Paris, 2001). Pengakategorian ini juga mendapat banyak kritik dan revisi dari berbagai akademisi. Ada sejumlah pendekatan mengenai kategori keamanan insani seperti Kanada, Jepang, Amerika Serikat, dll. Semua kategori ini sejalan dengan proses perluasan dan pendalaman makna keamanan. Roland Paris mendeskripsikan matriks studi keamanan sebagai berikut:

Diagram 1.

Matriks Tipologi Sumber Ancaman Keamanan

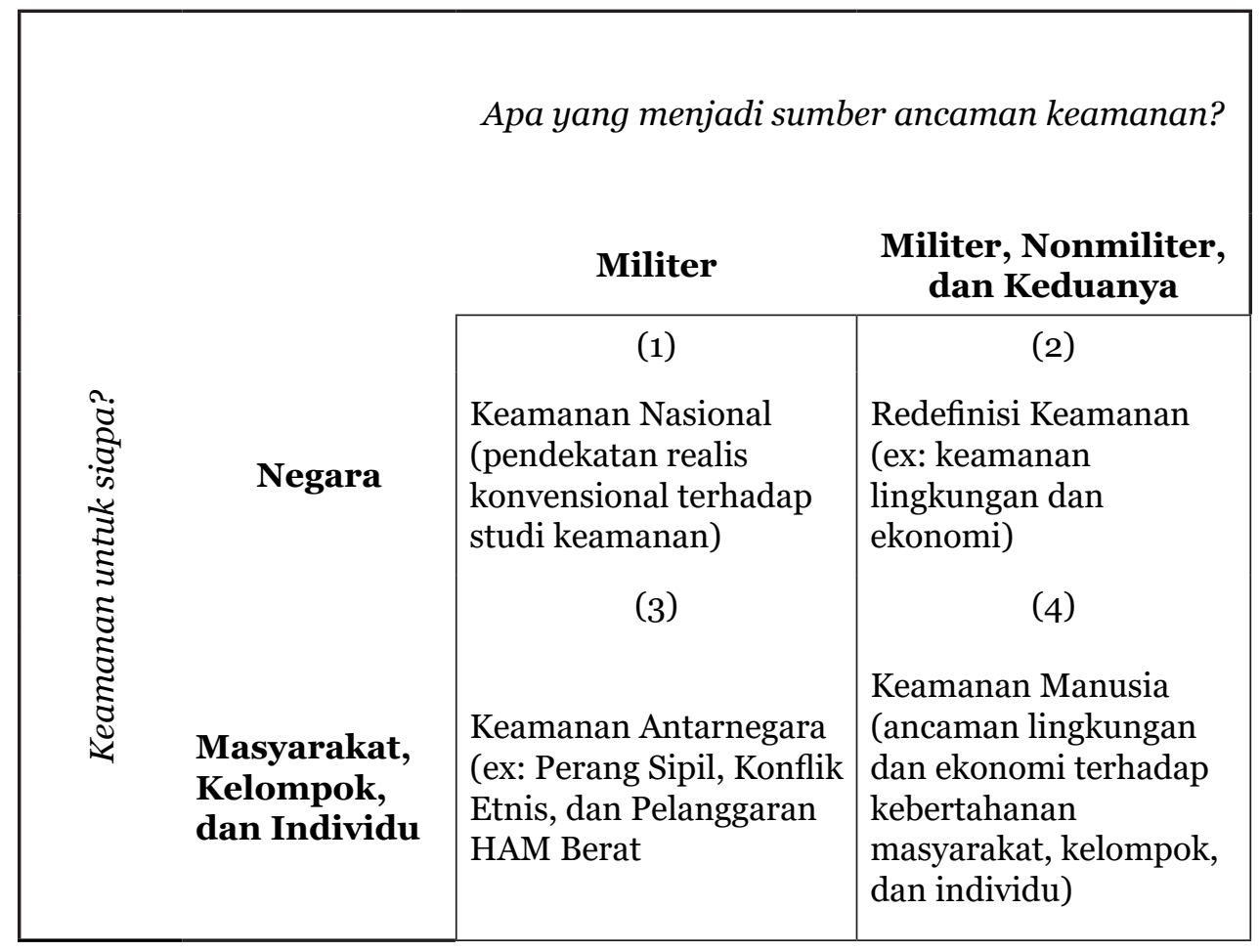

Sumber: Paris 2001, 87-102

Keamanan Insani telah dideskripsikan dengan banyak tafsiran dari banyak akademisi baik sebagai seruan, advokasi, kampanye politik, seperangkat keyakinan tentang 
sumber konflik, konseptualisasi baru keamanan, dan panduan untuk perumus kebijakan dan peneliti akademik. Keamanan insani adalah instrumen analisis yang baik namun perlu pengembangan akademik yang lebih jauh untuk menjadikannya sebagai kategori dalam sebuah riset keamanan.

Akademisi selanjutnya adalah Mohammed Ayoob yang melihat keamanan non tradisional dan ancaman non militer sebagai masalah negara dunia ketiga (negara berkembang). Ayoob yang menempatkan negara sebagai aktor utama menjelaskan bahwa masalah-masalah keamanan di negara berkembang dapat diatasi dengan cara State-Building dan State-Making. State-Building didefinisikan oleh Ayoob dengan mengutip definisi Jaggers sebagai kemampuan negara untuk mengakumulasi kekuatan. Kekuatan yang dimaksud tidak hanya produktivitas ekonomi dan ketegasan pemerintah, namun juga kekuatan institusi dan politik. Kekuatan (power) dapat dilihat dari tiga sudut pandang yaitu: 1) kekuatan sebagai kapabilitas nasional; 2) kekuatan sebagai kapasitas politik; dan 3) kekuatan sebagai koherensi institusional(Ayoob 1991).

Berangkat dari definisi ini, Ayoob mengenalkan dan menggunakan term StateMaking sebagai cara dan solusi negara-negara dunia ketiga menghadapi kesulitankesulitannya dengan tiga cara yaitu: 1) ekspansi dan konsolidasi wilayah teritorial dan demografi di bawah suatu otoritas politik yang kuat (militer; perang); 2) pengelolaan tatanan-tatanan dalam bentuk pranata-pranata tertentu terhadap populasi yang ada di teritori tersebut (kebijakan; administrasi dan birokrasi); dan 3) Ekstraksi sumber daya dari wilayah dan populasi yang ada di bawah kontrol negara, digunakan untuk menjalankan pemerintahan (perpajakan; ekonomi). Tiga poin ini adalah determinan dari proses State-Making menurut Ayoob. Penguatan tiga mata agenda tersebut akan menciptakan kondisi dimana negara tidak lagi bergantung pada kekuatan-kekuatan kolonial, negara tidak terdistorsi oleh kolonialisme dan negara mampu menghadapi popular demand di masyarakat sehingga proses state-making tidak mengalami kesulitan-kesulitan(Ayoob 1991).

Pandangan Ayoob tentang State-Making juga dituangkan dalam "Inequality and Theorizing in International Relations: The Case for Subaltern Realism" secara teoritis menerangkan bahwa teori-teori keamanan juga harus lepas dari pengaruh kolonialisme [teoritik]. Ayoob (2002) menekankan pada global society yang asli dan kesetaraan diantara negara-negara. Untuk mewujudkan ini, Ayoob berpandangan bahwa harus ada "sentralitas negara" (statism) yang diwujudkan dengan proses State Building dan/atau State Making.

Berdasarkan studi pustaka yang telah penulis diskusikan di awal, maka dapat disimpulkan beberapa proposisi baru yang dapat digunakan sebagai landasan atau kerangka acuan pemikiran dalam menyusun langkah strategis penanganan masalah keamanan nontradisional dan ancaman nonmiliter di daerah antara lain: 1) Pentingnya sentralitas negara (pemerintahan) dan institusionalisasi dalam menghadapi ancaman non militer, 2) Mengedepankan Tata Kelola Pemerintahan (governance) sebagai motor penggerak penyelenggaraan Tata Ruang Pertahanan Daerah, 3) Penting dan gentingnya sinergitas vertikal dan horizontal dalam menghadapi ancaman, tantangan, hambatan, dan gangguan pada keamanan non tradisional dan non militer. 4) Menjadikan komersialisasi dan teknologisasi keamanan opsi pendukung yang diperhitungkan dalam mendukung agenda Tata Ruang Pertahanan Daerah, serta 5) Memfasilitasi peran edukasi, advokasi, dan media massa sebagai instrument sosial dalam proses sosialisasi, pembangunan, dan perlindungan masyarakat. 
Pembangunan Pemerintahan (State-Building) untuk meningkatkan kapasitas nasional, politik, dan koherensi institusional dalam mendukung proses Pemberlakuan Pemerintahan (State-Making) untuk mewujudkan konsolidasi menguatkan otoritas politik, pranata pemerintahan (kebijakan, administrasi, dan birokrasi), dan ekstraksi sumber daya di bawah kontrol pemerintah (perpajakan, ekonomi, dan lain-lain).

\section{Dinamika Perkembangan Lingkungan Strategis}

Dinamika perkembangan lingkungan strategis pada tataran global, regional, dan nasional yang senantiasa berubah dapat berakumulasi menjadi berbagai bentuk ancaman, risiko, dan peluang bagi kepentingan nasional, baik secara langsung maupun tidak langsung. Ini dapat di lihat bagaimana situasi terkini yang terjadi di Semenanjung Korea, dimana keinginan Tiongkok untuk menguasai Laut Tiongkok Selatan dan Timur tanpa memerhatikan batas wilayah yang sudah disepakati, terutama dengan negara-negara Asean seperti Filipina, Malaysia, Vietnam dan Brunei Darussalam.

Tiongkok dengan kekuasaanya melakukan pembangunan armada militer laut dan pangkalan udara di semua perbatasan yang di sengketakan. Hal tersebut tentunya akan mengganggu keamanan dan stabilitas keamanan di kawasan. Amerika tentu tidak tinggal diam dan melakukan kebijakan-kebijakan untuk mereduksi Tiongkok untuk tumbuh dan berkembang. Berkembangnya kekuatan Tiongkok akan mengancam ekonomi, pertahanan dan keamanan Amerika kedepan. Amerika dengan sekutunya Australia mengeluarkan kebijakan Rebalancing Policy sebagai penyeimbang upaya Tiongkok menguasai Laut Tiongkok Selatan dan Laut TiongkokTimur menjadikan situasi semakin panas, dimana kedua negara melaksanakan latihan militer bersama sama dengan sekutunya sebagai show of power (menampilkan senjata mutakhir).

Kementerian Pertahanan Republik Indonesia (2015) lewat Buku Putih Pertahanan Indonesia 2015 memformulasikan sejumlah isu yang berpotensi menjadi ancaman dan kerawanan yang menjadi perhatian di lingkungan strategis global, regional, dan nasional. Diantaranya adalah ancaman seperti konflik intra-negara, terorisme, perkembangan ilmu pengetahuan dan teknologi, perubahan iklim, bencana alam, keamanan pangan, air, dan energi, serta epidemi. Perkembangan lingkungan strategis terkait dengan isu-isu ini menunjukkan gejala yang semakin eskalatif dan kompleks. Intensitasnya yang semakin dinamis membuat isu ini menjadi perhatian di tingkat global, regional, dan tentunya menjadi masalah nasional negara-negara.

\section{Perkembangan Global}

Kondisi global dewasa ini masih menghadapi berbagai konflik baik yang berdimensi militer maupun nonmiliter. Probabilitas pecahnya konflik militer masih tetap ada terkait dengan tingginya jurang perbedaan antara negara kaya dan miskin, persaingan memperebutkan sumber daya alam dan energi, serta pengamanan akses-akses strategis. Secara khusus, persaingan untuk mendapatkan sumber daya alam dan energi telah menimbulkan banyak ketegangan, bahkan konflik di berbagai kawasan terutama di wilayah yang dikategorikan kaya akan sumber daya strategis tersebut.

Permasalahan global yang saat ini dihadapi tidak lagi didominasi oleh ancaman militer, tetapi juga ancaman nonmiliter dalam dimensi ideologi, politik, ekonomi, dan sosial-budaya. Kondisi global di bidang politik mengalami perubahan yang 
signifikan dimana tuntutan masyarakat terhadap kualitas layanan pemerintah kepada masyarakat semakin tinggi. Apabila tuntutan tersebut tidak terwadahi dapat menjadi sumber konflik yang mengganggu jalannya fungsi pemerintahan. Bersamaan dengan itu dampak perubahan iklim secara global dirasakan oleh semua negara, yang berakibat pada kelangkaan pangan, energi, dan air bagi masyarakat dunia, serta berdampak negatif kepada perekonomian dunia yang dapat mengancam keamanan secara global. Sejumlah daerah yang ada di wilayah perbatasan negara merupakan wilayah Indonesia yang potensial menjadi sasaran dampak perkembangan lingkungan strategis global yang tidak terelakan dimana perkembangan lingkungan strategis global bisa menjadi kekuatan bagi bangsa Indonesia.

\section{Perkembangan Regional}

Kondisi regional saat ini masih diwarnai oleh beberapa isu ancaman aktual yang mencakup konflik perbatasan dan berbagai kejahatan lintas batas, seperti penyelundupan senjata, narkoba, penyelundupan manusia, pencurian kekayaan alam di darat maupun di laut, perompakan di laut, serta pelanggaran wilayah. Ancaman lain menanti dimana Indonesia, sebagai salah satu wilayah Asia Tenggara, memiliki letak/ kedudukan dalam rangkaian cincin api dan tempat bertemunya dua lempeng benua besar, yaitu lempeng Indo-Australia dan lempeng Eurasia. Pertemuan dua lempeng benua tersebut sering menyebabkan terjadinya gempa bumi di beberapa titik, bahkan rawan menimbulkan gelombang tsunami dan bencana alam lainnya berupa angin topan dan puting beliung, banjir bandang, serta ancaman baru berupa pandemi penyakit menular seperti flu burung, dan flu babi.

\section{Perkembangan Nasional}

Perkembangan nasional tidak luput dari permasalahan demografi. Sesuai dengan yang sudah diuraikan diatas, masalah demografi Indonesia termasuk di daerah yang dapat digolongkan dalam tiga kategori yakni pertambahan penduduk yang terus meningkat, jumlah masyarakat golongan bawah lebih besar dan semakin meningkat, dan penyebaran penduduk yang tidak merata. Hal tersebut menyebabkan terjadinya kepadatan penduduk di daerah-daerah tertentu, sementara daerah-daerah lain sangat jarang. Kondisi ini mengakibatkan terjadinya arus mobilisasi penduduk yang tinggi dan berpotensi memunculkan permasalahan sosial.

Kondisi sosial masyarakat saat ini secara umum dipengaruhi oleh beberapa faktor antara lain: euforia reformasi, pemahaman demokrasi yang keliru dari masyarakat, euforia otonomi daerah, heterogenitas masyarakat Indonesia dalam suku, agama, ras, antar golongan di berbagai daerah. Apabila hal ini tidak dikelola dengan baik, maka akan menjadi sumber konflik horizontal maupun vertikal dan tidak jarang berujung pada aksi anarkis yang dapat mengganggu jalannya pemerintahan di daerah. Berdasarkan perkembangan lingkungan strategis global, regional dan nasional, maka kemungkinan dinamika dan perkembangan situasi dalam negeri ke depan semakin kompleks. Kemungkinan terjadinya bencana alam, kerusakan infrastruktur di daerah, pemogokan massal, dan konflik komunal, serta permasalahan lainnya akan dihadapi oleh pemerintahan di daerah, yang membutuhkan sarana, alat dan kemampuan TNI. 


\section{Lingkungan Strategis dan Persepsi Ancaman Indonesia}

Perkembangan lingkungan strategis kini ikut menyertai pemahaman baru bahwa makna keamanan dan terminologi ancaman berkembang melahirkan jenis-jenis ancaman baru. Ancaman negara saat ini dapat digolongkan menjadi tiga antara lain ancaman militer, nonmiliter, dan ancaman hibrida. Berikut ini adalah jenis-jenis ancaman menurut Buku Putih Pertahanan Indonesia tahun 2015 yang telah penulis olah dalam sebuah matriks tabel.

Tabel 1.

Klasifikasi Ancaman Indonesia menurut Buku Putih Pertahanan

\begin{tabular}{|c|l|l|l|l|l|l|}
\hline \multirow{2}{*}{ No } & \multicolumn{2}{|c|}{ Isu } & \multicolumn{3}{c|}{ Dimensi } & \multicolumn{2}{c|}{ Klasifikasi } \\
\cline { 3 - 7 } & Spatialty & Referent Object & $\begin{array}{l}\text { Subject- } \\
\text { matter }\end{array}$ & Militer & Non \\
\hline 1 & $\begin{array}{l}\text { Modernisasi Kekuatan } \\
\text { Militer }\end{array}$ & Luar & State & High & v & \\
\hline 2 & Isu Perbatasan Antarnegara & Luar & State & High & v & \\
\hline $3 a$ & Konflik Intra & Dalam & Non State & High & v & \\
\hline $3 b$ & Konflik Antarnegara & Luar & State & High & v & \\
\hline 4 & $\begin{array}{l}\text { Kecenderungan) Konflik } \\
\text { Kontemporer }\end{array}$ & $\begin{array}{l}\text { Luar dan } \\
\text { Dalam }\end{array}$ & $\begin{array}{l}\text { State dan Non } \\
\text { State }\end{array}$ & $\begin{array}{l}\text { High dan } \\
\text { Low }\end{array}$ & v & v \\
\hline 5 & Senjata Pemusnah Massal & Luar & $\begin{array}{l}\text { State dan Non } \\
\text { State }\end{array}$ & High & v & \\
\hline 6 & Terorisme & $\begin{array}{l}\text { Dalam dan } \\
\text { Luar }\end{array}$ & State & High & v & \\
\hline 7 & Spionase & $\begin{array}{l}\text { Dalam dan } \\
\text { Luar }\end{array}$ & State & High & v & \\
\hline 8 & Kejahatan Lintas Negara & Luar & Non State & Low & & v \\
\hline 9 & $\begin{array}{l}\text { Perkembangan ilmu } \\
\text { pengetahuan dan teknologi } \\
\text { (Persenjataan dan ruang } \\
\text { siber }\end{array}$ & Luar & State & Low & & v \\
\hline 10 & Perubahan Iklim & $\begin{array}{l}\text { Dalam dan } \\
\text { Luar }\end{array}$ & Non State & Low & & v \\
\hline 11 & Bencana Alam & $\begin{array}{l}\text { Dalam dan } \\
\text { luar }\end{array}$ & Non State & Low & & v \\
\hline 12 & $\begin{array}{l}\text { Keamanan Pangan, Air, dan } \\
\text { teknologi }\end{array}$ & Dalam & Non State & Low & & v \\
\hline 13 & Epidemi & $\begin{array}{l}\text { Dalam dan } \\
\text { Luar }\end{array}$ & Non State & Low & & v \\
\hline 14 & $\begin{array}{l}\text { Perkembangan Lingkungan } \\
\text { strategis nasional : }\end{array}$ & Dalam & State & Low & & v \\
\hline $14 a$ & Ideologi & Dalam & State & Low & & v \\
\hline $14 b$ & Politik & Eon State & Low & & v \\
\hline $14 c$ & Ekonomi & & & & \\
\hline & & & & & \\
\hline
\end{tabular}




\begin{tabular}{|c|c|c|c|c|c|c|}
\hline $14 d$ & Sosial Budaya & Luar & Non State & Low & & $\mathrm{V}$ \\
\hline $14 e$ & $\begin{array}{l}\text { Keamanan Dalam Negeri } \\
\text { (contoh: separatisme) }\end{array}$ & Dalam & State & High & $\mathrm{v}$ & \\
\hline 15 & $\begin{array}{l}\text { Prediksi ancaman nyata ke } \\
\text { depan: }\end{array}$ & & & & & \\
\hline $15 a$ & Terorisme dan Radikalisme & $\begin{array}{l}\text { Dalam dan } \\
\text { Luar }\end{array}$ & State & High & $\mathrm{v}$ & \\
\hline $15 b$ & $\begin{array}{l}\text { Separatisme dan } \\
\text { Pemberontakan Bersenjata }\end{array}$ & Dalam & State & High & $\mathrm{v}$ & \\
\hline $15 c$ & Bencana Alam & $\begin{array}{l}\text { Dalam dan } \\
\text { luar }\end{array}$ & Non State & Low & & $\mathrm{v}$ \\
\hline $15 d$ & $\begin{array}{l}\text { Pelanggaran Wilayah } \\
\text { Perbatasan }\end{array}$ & Luar & State & High & $\mathrm{v}$ & \\
\hline $15 e$ & $\begin{array}{l}\text { Perompakan dan Pencurian } \\
\text { Kekayaan Alam }\end{array}$ & Luar & State & Low & & $\mathrm{v}$ \\
\hline $15 f$ & Wabah Penyakit & $\begin{array}{l}\text { Dalam dan } \\
\text { Luar }\end{array}$ & Non State & Low & & $\mathrm{v}$ \\
\hline 159 & $\begin{array}{l}\text { Serangan Siber dan } \\
\text { Spionase }\end{array}$ & $\begin{array}{l}\text { Dalam dan } \\
\text { Luar }\end{array}$ & State & High & $\mathrm{v}$ & \\
\hline $15 h$ & Narkoba & $\begin{array}{l}\text { Dalam dan } \\
\text { Luar }\end{array}$ & Non State & Low & & $\mathrm{v}$ \\
\hline 16 & $\begin{array}{l}\text { Prediksi ancaman belum } \\
\text { nyata ke depan: }\end{array}$ & & & & & \\
\hline $16 a$ & $\begin{array}{l}\text { Konflik Terbuka/Perang } \\
\text { Konvensional }\end{array}$ & Luar & State & High & $\mathrm{V}$ & \\
\hline
\end{tabular}

Sumber: Diolah dari Buku Putih Pertahanan Indonesia, 2015

Tabel di atas menunjukkan klasifikasi ancaman dan kerawanan yang ada di Indonesia dan secara khusus juga berpotensi hadir dan berkembang di daerah. Spatialty dimaksudkan pada asal ancaman tersebut apakah datang dari luar atau dalam teritori daerah dan/atau negara. Aspek Referent Object mengindikasikan pihak yang terancam dan perlu untuk disediakan keamanan oleh aktor penyedia keamanan. Kemudian Subject Matter ditujukan kepada kualitas ancaman apakah bersifat krusial (high) atau tidak (low). Tabel 1 di atas merangkum seluruh ancaman dan kerawanan yang ada di Indonesia beserta klasifikasi apakah ia termasuk dalam kategori tradisional (militer) atau nontradisional (nonmiliter).

\section{Sekuritisasi Ancaman Nonmiliter dan Sinergitas Pembangunan Tata Ruang Pertahanan Daerah}

Untuk memperkuat sinergitas vertikal dan horizontal penanganan ancaman nonmiliter, penulis menawarkan sebuah kerangka sekuritisasi berdasarkan pada pemikiran Mely Caballero-Anthony dan Alistair D.B. Cook (2013) dalam "Non-Traditional Security in Asia". Terdapat lima langkah yang dijalani pemerintah dalam menentukan status ancaman suatu masalah hingga sampai pada perumusan kebijakan terkait dengan penanganan ancaman tersebut. Langkah-langkah tersebut adalah: 
Pertama, Issue Area. Merupakan proses identifikasi masalah yang terjadi dan menguji tingkat kerawanan dan destabilitas yang secara aktual dan/atau potensial terjadi. Proses ini adalah dimana aktor baik pemerintah maupun masyarakat meyakinkan audience bahwa suatu daerah tertentu tengah menghadapi ancaman eksistensial (existential threat). Pada tataran ini harus ada audience sebagai ukuran keawasan masyarakat dan/atau pemerintah tentang suatu ancaman yang muncul dan berkembang. Kedua, Securitizing Actor(s). Tahap ini menentukan dan mengidentifikasi siapa yang menjadi aktor utama dalam melakukan usaha-usaha pertahanan dan keamanan. Disini letak peran tidak hanya negara mampu menjadi aktor pengamanan.

Ketiga, Security Concepts. Tahap ini berkaitan dengan identifikasi "keselamatan siapakah" yang menjadi masalah utama. Dengan bahasa lebih mudah, "siapakah yang diserang?". Bisa masyarakat dan bisa juga pemerintah itu sendiri. Tahap ini adalah tahap penentuan "referent object" atau "yang diamankan". Keempat, Process. Tahap ini adalah tahap dimana keberadaan suatu masalah dan ancaman secara potensial maupun aktual disuarakan dan disosialisasikan ke lapisan masyarakat luas dengan sebuah bentuk "Speech Act". Secara sederhana, speech act berbicara tentang "pernyataan apa yang dikeluarkan oleh pihak berwenang terkait dengan isu?" (sebagai contoh: speech act Presiden Joko Widodo yang mengatakan bahwa Indonesia saat ini sedang "Darurat Narkoba”. Ini adalah pernyataan yang menjelaskan bahwa saat ini negara tengah menghadapi ancaman peredaran dan penyalahgunaan narkoba.

Kelima, Intervening Variables. Merupakan faktor-faktor yang menjadi determinan menguat dan melemahnya proses sekuritisasi yang dilakukan. Tahapini memiliki empat faktor yaitu: 1) perbedaan konsepsi dan persepsi tentang keamanan dan ancaman yang saling mempengaruhi; 2) kaitan-kaitan suatu ancaman dan/atau kerawanan terhadap isu-isu yang lain yang potensial menjadi sebuah ancaman; 3) peran para pemangku kepentingan dan perumus kebijakan; dan 4) sistem politik domestik suatu negara dan/atau daerah yang cukup banyak menentukan proses sekuritisasi.

Berdasarkan pada pemikiran Mely Caballero-Anthony dan Alistair D.B. Cook (2013) dalam "Non-Traditional Security in Asia" tentang lima tahapan dalam melakukan usaha sekuritisasi, lima tahapan tersebut harus diperkuat dan didukung dalam sebuah kerangka kerja yang mengikuti ruang lingkup otonomi daerah sebagai topik utama yang penulis angkat. Agenda tersebut penulis sebut sebagai "Evaluasi Kebijakan dan Analisis Tata Kelola Pemerintahan". Agenda ini berguna dalam menganalisis kekuatan, kelemahan, kesempatan, ancaman yang dihadapi/dimiliki suatu aktor negara maupun daerah dalam menangani sebuah ancaman, dalam hal ini adalah ancaman non militer. Analisis ini juga menghasilkan solusi strategis bagi pihak terkait dalam merumuskan kebijakan penanganan ancaman non militer dan tata ruang pertahanan daerah dalam rangka penyelenggaraan pertahanan negara di daerah. Penulis memberikan syarat utama yang harus dipenuhi oleh pemerintah antara lain: 1) Partisipasi, 2) adanya kerangka hukum yang kuat, 3) transparansi, 4) adanya kebijakan yang responsif, 5) Perumusan kebijakan yang berorientasi pada konsensus, 6) perlunya prinsip inklusif dan keadilan, 7) perlunya kebijakan yang efektif dan efisien serta 8) adanya akuntabilitas.

Delapan syarat ini adalah syarat yang harus dipenuhi setiap pemangku kepentingan dan perumus kebijakan untuk mewujudkan sebuah sinergitas yang komprehensif secara vertikal dan juga horizontal. Delapan variabel ini dapat mendorong sebuah tata kelola pemerintahan daerah yang baik dan mendukung pembangunan tata ruang 
pertahanan daerah dalam penyelenggaraan pertahanan negara di daerah.

Enam masalah utama yang menyertai daerah dalam menangani ancaman nonmiliter dapat diselesaikan dengan enam solusi utama berupa enam langkah strategis yang dirumuskan berdasarkan pada analisis tata kelola pemerintahan, data, pemahaman teoritik, dan visi perencanaan berkelanjutan yang telah penulis kemukakan di awal. Solusitersebut antara lain pertama, revitalisasi sentralitas peran negara (pemerintahan) dan institusionalisasi dalam menghadapi ancaman nonmiliter. Kedua, tata kelola pemerintahan yang baik (good governance; governansi) sebagai motor penggerak penyelenggaraan Tata Ruang Pertahanan Daerah, yang masih sulit untuk menjadi motor penggerak perlawanan terhadap ancaman nonmiliter dibuktikan dengan masih rendahnya kualitas Aparatur Sipil Negara di daerah. Ketiga, adanya sinergitas vertikal dan horizontal dalam menghadapi ancaman, tantangan, hambatan, dan gangguan pada keamanan nontradisional dan nonmiliter dengan membentuk badan dan/atau kebijakan khusus dari Pemerintah Provinsi yang dikoordinasikan dengan Pemerintah Pusat. Keempat, menginisiasi digitalisasi opsi pendukung yang diperhitungkan dalam mendukung agenda Tata Ruang Pertahanan Daerah. Kelima, Membangun fasilitas edukasi, advokasi, dan media massa sebagai instrumen sosial dalam proses sosialisasi, pembangunan, dan perlindungan masyarakat yang belum berjalan dengan baik. Serta yang terakhir, Merencanakan dan melaksanakan Pembangunan Pemerintahan (State-Building) untuk meningkatkan kapasitas nasional, politik, dan koherensi institusional dalam mendukung proses Pemberlakuan Pemerintahan (State-Making) untuk mewujudkan konsolidasi menguatkan otoritas politik, pranata pemerintahan (kebijakan, administrasi, dan birokrasi), dan ekstraksi sumber daya di bawah kontrol pemerintah (perpajakan, ekonomi, dan lain-lain). Dua aspek ini masih menjadi masalah utama tidak hanya di tingkat daerah, namun juga daerah-daerah lain, dan bahkan Indonesia sebagai pemerintah pusat.

Enam solusi utama di atas tidak dapat dilakukan tanpa perencanaan dan pelaksanaan yang terstruktur dan tersistemasi dengan baik secara lingkup ruang dan lini waktu. Oleh karena itu, sebuah kerangka matriks sinergitas peran dan kebijakan publik untuk mendorong strategi pemerintah dan komponen daerah dalam menghadapi dan menangani permasalahan-permasalahan yang bersumber dari ancaman-ancaman dan kerawanan nonmiliter, baik ancaman aktual maupun ancaman potensial dapat dilihat pada Tabel 1. Berikut adalah matriks kerangka sinergitas peran yang telah penulis susun. 
Tabel 2.

Matriks Sinergitas Peran Penanganan Ancaman Nirmiliter Pusat dan Daerah

\begin{tabular}{|c|c|c|c|}
\hline & $\begin{array}{l}\text { Stakeholder - Penanggung } \\
\text { Jawab }\end{array}$ & & Peran \\
\hline \multirow[t]{3}{*}{1} & \multirow[t]{3}{*}{ TNI } & Korem & $\begin{array}{c}\begin{array}{c}\text { Pembinaan } \\
\text { Teritorial }\end{array} \\
\end{array}$ \\
\hline & & Kasrem & $\begin{array}{l}\text { Fungsi Organik } \\
\text { Militer sebagai } \\
\text { Pendukung Tugas } \\
\text { Pokok Korem } \\
\end{array}$ \\
\hline & & Kasiintel & $\begin{array}{l}\text { Fungsi Organik } \\
\text { Militer (kegiatan } \\
\text { intelijen) }\end{array}$ \\
\hline 2 & Polri & Polda & $\begin{array}{l}\text { Penegakan hukum, } \\
\text { pemeliharaan } \\
\text { ketertiban dan } \\
\text { keamanan daerah }\end{array}$ \\
\hline \multirow[t]{2}{*}{3} & \multirow[t]{2}{*}{ Pemerintah Provinsi } & Kesbangpol Provinsi & $\begin{array}{l}\text { Pembinaan } \\
\text { Ketahanan Nasional } \\
\text { dan Wawasan } \\
\text { Kebangsaaan } \\
\end{array}$ \\
\hline & & Bappeda Provinsi & $\begin{array}{l}\text { Perencanaan } \\
\text { Kebijakan tentang } \\
\text { Kamnontrad dan } \\
\text { Ancaman Nirmiliter }\end{array}$ \\
\hline \multirow[t]{2}{*}{4} & \multirow[t]{2}{*}{$\begin{array}{l}\text { Pemerintah Daerah } \\
\text { Kabupaten/Kota }\end{array}$} & Kesbangpol & $\begin{array}{l}\text { Pembinaan } \\
\text { Ketahanan Nasional } \\
\text { dan Wawasan } \\
\text { Kebangsaaan } \\
\end{array}$ \\
\hline & & Bappeda & $\begin{array}{l}\text { Perencanaan } \\
\text { Kebijakan tentang } \\
\text { Kamnontrad dan } \\
\text { Ancaman Nirmiliter }\end{array}$ \\
\hline 5 & BIN & BINDA & $\begin{array}{l}\text { Pengkajian dan } \\
\text { penyusunan } \\
\text { kebijakan intelijen; } \\
\text { suplai informasi } \\
\text { intelijen }\end{array}$ \\
\hline 6 & $\mathrm{BNN}$ & BNNP & $\begin{array}{l}\text { Data, Informasi, } \\
\text { Penanggulangan, } \\
\text { dan Rehabilitasi }\end{array}$ \\
\hline 7 & BNPB & BNPB Daerah & $\begin{array}{l}\text { Penanggulangan } \\
\text { Bencana Alam } \\
\text { sebagai salah satu } \\
\text { ancaman nirmiliter }\end{array}$ \\
\hline
\end{tabular}




\begin{tabular}{|c|l|l|l|}
\hline 8 & $\begin{array}{l}\text { Kementerian dan } \\
\text { Kelembagaan }\end{array}$ & PPTP Kemhan Daerah & $\begin{array}{l}\text { Perumusan, } \\
\text { penetapan, dan } \\
\text { pelaksanaan } \\
\text { kebijakan } \\
\text { pertahanan di } \\
\text { daerah }\end{array}$ \\
\hline 9 & Akademisi & Universitas & $\begin{array}{l}\text { Edukasi, Penelitian, } \\
\text { Pengabdian, dan } \\
\text { Pengembangan } \\
\text { Masyarakat }\end{array}$ \\
\hline 10 & DPR/MPR & $\begin{array}{l}\text { Dewan Perwakilah } \\
\text { Rakyat Daerah }\end{array}$ & $\begin{array}{l}\text { Merumuskan perda } \\
\text { penait dengan } \\
\text { ancamanan nirmiliter }\end{array}$ \\
\hline 11 & Media Massa & Media Massa di daerah & $\begin{array}{l}\text { Mengedukasi dan } \\
\text { sosialisasi tentang } \\
\text { bahaya ancaman } \\
\text { nirmiliter di daerah }\end{array}$ \\
\hline 12 & Masyarakat Sipil & $\begin{array}{l}\text { Organisasi Masyarakat } \\
\text { di Daerah }\end{array}$ & $\begin{array}{l}\text { Advokasi dan } \\
\text { Edukasi masyarakat } \\
\text { tentang Kamnontrad } \\
\text { dan Ancaman } \\
\text { Nirmiliter }\end{array}$ \\
\hline
\end{tabular}

Sinergitas penanganan ancaman nirmiliter dan pembangunan tata ruang pertahanan daerah setidaknya melibatkan dua belas sektor yang terdiri dari pemerintah, militer, kepolisian, dan masyarakat sipil. Masing-masing sektor memiliki perwakilan dan/atau pelaksana tugas pokok di daerahnya, termasuk di daerah. Masing-masing penanggung jawab ini memiliki wewenang dan kewajiban tugas. Sinergitas peran ini sangat diperlukan untuk mendorong penanganan ancaman nirmliter dan pembangunan tata ruang pertahanan daerah menjadi lebih efektif dan efisien.

Sinergitas peranan ini diharapkan dapat mencapai tujuan-tujuan strategis baik secara makro, mikro dan jangka panjang ataupun menengah, dan pendek. Berikut adalah matriks kerangka kerangka kebijakan publik penanganan ancaman nirmliter di daerah dan pembangunan tata ruang pertahanan daerah yang telah penulis susun. Setiap dua belas instansi atau sektor yang ada pada tabel 3 , mengemban tugas dan kewajiban di setiap area pada matriks kebijakan publik di bawah ini. Berikut adalah matriks kebijakan publik sebagai panduan atau strategic roadmap dalam menangani ancaman nirmiliter di daerah. 
Sinergitas Pembangunan Tata Ruang Pertahanan Daerah dalam Menghadapi Ancaman

Non-Militer di Indonesia

Tabel 3

Matriks Kebijakan Publik dalam Menangani Ancaman Nirmiliter

\begin{tabular}{|c|c|c|c|}
\hline & \multicolumn{3}{|c|}{ Jangka Waktu } \\
\hline $\begin{array}{c}\text { Ruang } \\
\text { Lingkup }\end{array}$ & Pendek & Menengah & Panjang \\
\hline Makro & $\begin{array}{c}\text { Sentralitas dan } \\
\text { Institusionalisasi Negara }\end{array}$ & $\begin{array}{c}\text { Membentuk Satuan Tugas } \\
\text { Khusus sebagai Bentuk } \\
\text { Sinergitas Vertikal dan } \\
\text { Horizontal }\end{array}$ & $\begin{array}{c}\text { State-Building dan State- } \\
\text { Making }\end{array}$ \\
\hline Mikro & $\begin{array}{c}\text { Tata Kelola Pemerintahan } \\
\text { (peningkatan kualitas ASN) }\end{array}$ & $\begin{array}{c}\text { Meningkatkan Fasilitas } \\
\text { Edukasi, Advokasi, dan } \\
\text { Media Massa }\end{array}$ & $\begin{array}{c}\text { Komersialisasi dan } \\
\text { Teknologisasi Keamanan }\end{array}$ \\
\hline
\end{tabular}

\section{Simpulan}

Dari uraian sebelumnya mengenai sinergitas pembangunan di daerah guna menghadapi ancaman nonmiliter dalam rangka mendukung penyelenggaraan pertahanan negara, dapat disimpulkan bahwa sinergitas pembangunan nasional, pembangunan daerah dan pembangunan pertahanan negara perlu disinkronkan dengan didukung regulasi yang jelas, dengan memperhitungkan sumber daya yang tersedia guna tercapainya kesejahteraan masyarakat yang nyata, baik dalam aspek pendapatan, kesempatan kerja, lapangan usaha, akses terhadap pengambilan kebijakan, berdaya saing, maupun peningkatan indeks pembangunan manusia. Sinergitas antar pemangku kepentingan dalam sinergitas pembangunan pertahanan negara merupakan hal yang pokok untuk mencapai pertahanan yang tangguh. Kemudian, sosialisasi kebijakan antar Instansi Vertikal Kementerian/Lembaga dan Pemerintah Daerah perlu dioptimalkan dan diintensifkan sehingga akan tercapai suatu persamaan persepsi dalam pengelolaan dan penyelenggaraan pembangunan pertahanan negara. Regulasi komponen pertahanan negara agar dapat segera terealisasikan dan dapat diimplemenetasikan dalam pengelolaan pertahanan negara sehingga tidak terjadi tumpang tindih (overlapping) program pembangunan.

Adapun rekomendasi yang dapat diberikan dalam kajian sinergitas pembanguan di daerah guna mencapai target kebijakan publik berdasarkan pada matriks acuan kebijakan strategis yang telah penulis ajukan dapat dilakukan dengan langkahlangkah strategis awal berikut antara lain pertama, perlu segera direalisasikan oleh pemerintah pusat untuk regulasi yang mengatur Sistem Keamanan Negara yang memuat pengelolaan dan penyelengaraan tentang Komponen cadangan dan Komponen Pendukung, serta unsur lain pada sistem Pertahanan Negara dalam rangka menghadapi ancaman nonmiliter di daerah. Kedua, perlu membangun komunikasi sosial antar para pemangku kepentingan Instansi Vertikal/ Lembaga dan daerah dalam pengelolaan an penyelenggaraan pembangunan. Ketiga, perlu reaktualisasi kinerja Badan/lembaga dari SKPD Kabupaten/Kota Provinsi dari para pemangku kepentingan harus lebih optimal dalam rangka mengkoordinir dan mengawasi pembangunan nasional di daerah. Dan yang terakhir, perlu optimalisasi pelaksanaan sosialisasi Kebijakan Pembangunan Nasional dan Kebijakan Pertahanan negara antar Instansi Vertikal Kementerian/Lembaga dan Pemerintah daerah secara berkesinambungan. 


\section{Referensi}

\section{Buku}

Burgees, J. P. 2007. Non-Military Security Challenges. In C. A. Snyder, Contemporary Security and Strategy. London : Palgrave Macmillan.

Buzan, B. 1983. People, State, and Fear: The National Security Problem in International Relations . Brighton/Sussex: Wheatsheaf Books.

Caballero-Anthony, M., \& Cook, A. D. 2013. Non-Traditional Security in Asia: Issues, Challenges, and Framework for Action . Singapura: Institute od Southeast Asian Studies.

Thornton, R. 2007. Asymmetric Warfare. Cambridge: Polity Press.

\section{Jurnal}

Ayoob, M. 1991. The Security Problematic of the Third World. World Politics Vol. 43 No. 2, 257-283.

Ayoob, M. 2002. Inequality and Theorizing in International Relations: The Case for Subaltern Realism. International Studies Review Vol. 4 No. 3, 27-48.

Caballero-Anthony, M. 2010. Non-Traditional Security Challenges, Regional Governance, and the ASEAN Political-Security Community. Asia Security Initiative Politcy Series, Working Paper No.7.

Paris, R. 2001. Human Security: Paradigm Shift or Hot Air. International Security Vol. 26 No. 2, 87-102.

Sebastian, L. 2006. Realpolitik Ideology: Indonesia's Use of Military Force. Singapura: ISEAS.

Wiberg, H. 1995. Social and Cultural Origins of Violence: Non-Military Aspects of International Security. In UNESCO, Non-military Aspects of International Security. New York: UNESCO.

\section{Artikel Daring}

Antara News. 2015. Delapan Ancaman Negara Nirmiliter menurut Menteri Pertahanan., [daring] dalam http://www.antaranews.com/berita/523063/ delapan-ancaman-negara-nirmiliter-menurut-menteri-pertahanan [diakses pada 9 Agustus 2017]

Kompas. 2016. Menhan Minta Perguruan Tinggi Cetak Intelektual Bela Negara. [daring] dalam, http://nasional.kompas.com/read/2016/03/29/17563461/ Menhan.Minta.Perguruan.Tinggi.Cetak.Intelektual.Bela.Negara [diakses pada 9 Agustus 2017] 
Sinergitas Pembangunan Tata Ruang Pertahanan Daerah dalam Menghadapi Ancaman Non-Militer di Indonesia

\section{Lain-Lain}

Kementerian Pertahanan. 2015. Buku Putih Pertahanan Indonesia 2015. Jakarta: Kementerian Pertahanan Republik Indonesia. 